\title{
Designing advertising strategies for the Armenti Coffee House
}

\author{
I. Sumargono \& A.P. Ayu \\ Telkom University, Bandung, Indonesia
}

\begin{abstract}
The Armenti Coffee House is one of the coffee shops in Bandung that has the vision to make its coffee shop educational. Here, customers can deepen their insight into the coffee as well as have the unique experience of making their own coffee while learning about coffee processing. Based on the results of the interview analysis, the lack of maximum branding activity makes the target audience unable to recognize Armenti as an educational coffee shop. Also, many consumers want to learn about coffee, but Armenti is not their choice of places to study. This research uses qualitative methods in collecting data, in the form of observation, interviews, and literature study. The data obtained were analyzed using SWOT, AIO, and AISAS. The author makes a series of branding and promotions with the theme "Ragam Literasi Rasa," with the goal of increasing awareness and recognition of The Armenti Coffee House.
\end{abstract}

Keywords: Armenti, branding, educative, promotion

\section{INTRODUCTION}

The Armenti Coffee House, established in Bandung in September 2018, is one of the small- and medium-sized companies engaged in the coffee industry. Besides selling coffee, Armenti also has a pleasant cafe atmosphere, a spacious, clean, and comfortable environment, excellent coffee quality, and adequate coffee equipment, ranging from manual coffee machines to automatic ones. Along with it serving third-wave coffee (high-quality coffee elevated to an art form) and supported by its facilities, Armenti also hopes to create a coffee shop that is well known in the community as an educational coffee shop.

Compared to other coffee shops, the Armenti Coffee House provides more experiences with which customers can learn about the coffee-making process. It aims to educate the public to know more about coffee. This unique experience is also supported by visual brand activation, including logos and colors, as well as communication and non-visual behavior (Pamungkas 2018). Unfortunately, due to lack of visual marketing such as slogans and mascots, the image of Armenti's coffee shop as an educative coffee shop is not yet formed. At the same time, according to Judisseno (2019), creating good branding for consumers must be a provider of ideas and inspiration, as well as a provider of experience. Besides, the existing brand strategy is still not optimal, so it does not build a unique and valuable position in the minds of consumers. This is proved by the lack of association of the Armenti Coffee House in the minds of consumers as an educative coffee shop.

Based on the results of the questionnaire and interview, many of the target audience of the Armenti Coffee House cannot associate Armenti with being an educational coffee shop. This is unfortunate, considering that many of the target audience want to learn and deepen their insights about coffee, but do not know where to go, however Armenti is not a choice in their minds for that.

In designing this advertising strategy, maximum branding and promotion activations will be carried out to increase brand equity in the category of the Armenti Coffee House brand association and create a unique position in the minds of consumers.

Based on the background, the problem was formulated on how to design the right branding strategy and promotion for the Armenti Coffee House. Issues that will be discussed in the design 
of advertising strategies for the Armenti Coffee House will go through a series of branding and promotional activities, with a creative strategy approach and the media. The AISAS method is believed to be the most appropriate to carry out this activation because this method was created effectively by observing the behavior of the target audience (Sugiyama \& Andree 2011).

\section{RESEARCH METHODS}

The methodology used in this study was the qualitative data approach utilizing observation activities by making observations to gain empirical experience, understand the context of the data, and discover the situations that occur in the field. First, such observations were done by visiting the Armenti Coffee House which is located on Jl. Reog No.6A, Turangga, Bandung, to meet staff and observe the situation in the café. Second, interviews are conducted to obtain information or ideas to gain deeper understanding. In this interview method, the writer interviewed the Head of the Business Unit at the Armenti Coffee House, Mr. Dwi Anggiadi. Finally, method was literature study. The authors used book sources, journals and other sources for reference.

\section{RESULT AND DISCUSSION}

In the creative strategy, the authors first analyze the brand value using the SWOT matrix. After analyzing the matrix, the authors use the strength and opportunity matrix to enhance the chances to compete with other competitors. In the media strategy, the author uses the AISAS method to project the effective media to approach the target audience.

As stated by Kotler et al. (2016), branding is a process of providing brand strength or value to products and services. This is to facilitate the identification and make a difference in the product. So, branding needs to be done so that Armenti has brand strength and a striking difference compared to its competitors through its messaging and visual aspects.

Tagline. The authors designed the tagline for the Armenti Coffee House based on the analysis of the S-O strategy. This tagline is useful for influencing customer buying behavior by evoking an emotional response. Also, the tagline contains the positioning of the company, thus differentiating it from its competitors (Swasty 2016). The tagline for Armenti is "Ragam Literasi Rasa."

Logo. In the process of activating branding conducted for the Armenti Coffee House, a new logo is formed to facilitate the delivery of messages to be conveyed by Armenti. The logo itself is the character or identity of a product or service (Pratiwi \& Sumargono 2019). The formation of a new logo helps to make Armenti a cultural icon, participate in building ownership, and value development (Budeimann 2010).

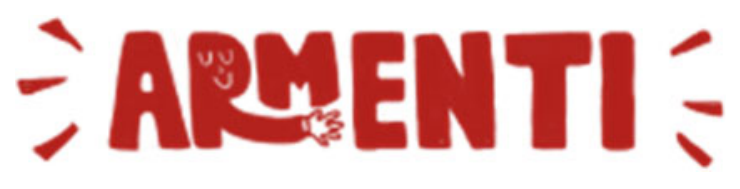

Figure 1. Armenti's new logo. (Source: Personal).

Mascot. The mascot was formed on the branding strategy to facilitate the target audience to associate the Armenti Coffee House. Besides, according to Delbare in Hoolwerff (2014), the formation of a mascot can bring brand attributes or the value of the Armenti itself.

Promotion. Regarding the concept of promotion, Armenti has to communicate with its target audience to inform, persuade, and remind consumers about the products and brands they sell. The authors use the AISAS method to adequately influence the target audience. 


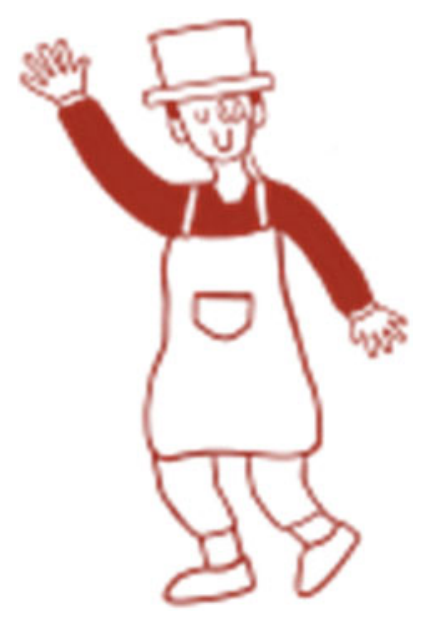

Figure 2. Armenti mascot. (Source: Personal).

Attention. To attract the attention of Armenti consumers and increase awareness of brand activation carried out by the Armenti Coffee House, digital poster media, Instagram filters, and Instastory advertisements were created.

Interest. In the interest stage, the main media becomes the advertising strategy of the Armenti Coffee House. At this stage, the main media is in the form of advertisements with video formats. They contain a message about the advantages that exist in the Armenti Coffee House.

Search. The media search stage used aims to support awareness of the attention and interest stages using an informative and persuasive communication strategy through explanatory content on social media, while still selling their products through the website.

Action. The activity carried out was organizing a coffee class where the event contained a brewing competition, cupping session, and a seminar. This is to support the tagline "Ragam Literasi Rasa," which aims to increase the target audience's literacy toward coffee. There is also a social media challenge called "Doodle Your Cup" to help increase Armenti sales shares. In addition to using hashtags that will be included in all media, the use of Instagram templates in Instastory also facilitates the activation of the Armenti brand to be distributed to a wider target audience.

On the attention stage poster, visuals related to coffee will be displayed, such as barista activities, coffee beans, and latte art. As for the advertising poster, it contains provocative writing which will be related to a video in the interest stage.
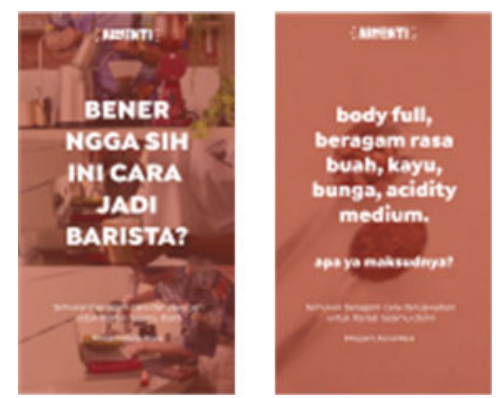

Figure 3. Armenti Coffee House digital poster. (Source: Personal). 
The video advertisement becomes the main media in the advertising strategy of the Armenti Coffee House. At this stage, the main media in the form of advertisements with video formats and contains a message about the advantages that exist at the Armenti Coffee House.

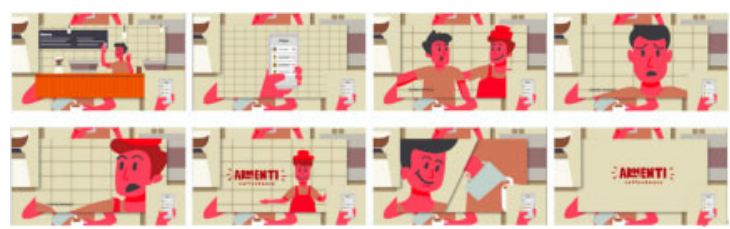

Figure 4. Armenti Coffe House video ad. (Source: Personal).

To gain a wider audience, Armenti uses contents on their social media.

a. Instagram Filter
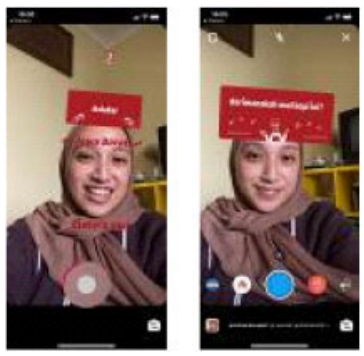

Figure 5. Armenti Instagram filter (Source: Personal).

b. Instagram Explanatory Content
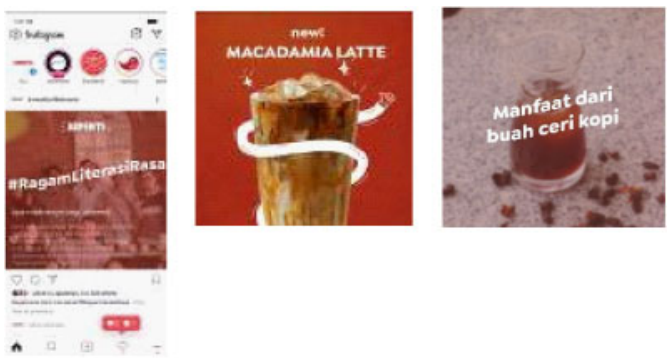

Figure 6. Instagram explanatory content. (Source: Personal).

The website will be a bridge for the target audience who want to find more information about the process of making coffee. On the website, there is also information on class schedules, as well as testimonies from people who have taken classes at the Armenti Coffee House.

There are two events that will be held in the activation of the Armenti Coffee House branding. The first is the coffee class event, which will be held to coincide with International Coffee Day. This activity will be broadcast live on Armenti's social media. In addition, before welcoming the Coffee Class and International Coffee Day, a social media challenge will take place with the concept of 

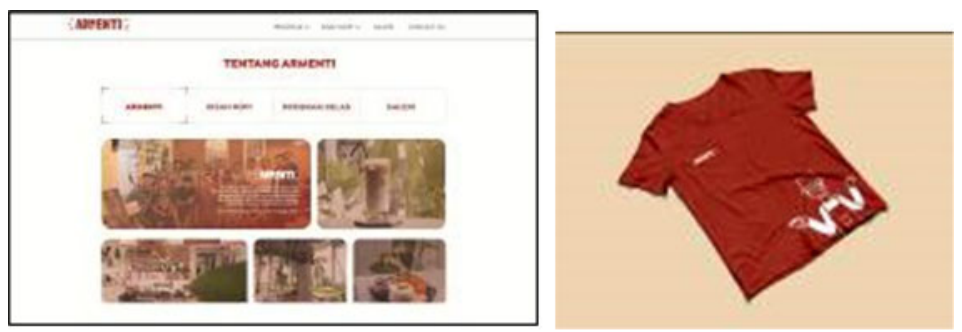

Figure 7. Website. (Source: Personal).
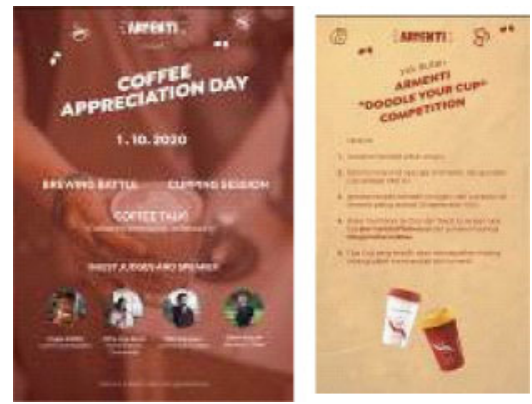

Figure 8. Event at the Armenti Coffee House. (Source: Personal).

"Doodle Your Cup." The winner of the competition will be announced on Coffee Day and receive merchandise from Armenti as a prize.

\section{CONCLUSION}

Based on the results of observations, interviews, and data processing, the authors can conclude that the Armenti Coffee House is still not optimal in carrying out a series of branding and promotional activities. This can be seen from the non-maximum brand identity and promotion in order to communicate the strengths of Armenti. Customers still don't associate Armenti with an educative coffee shop.Through designing this advertising strategy, the authors create a series of brand activations in the form of brand identity, and a series of promotions as a medium to communicate with the target audience. This is considered appropriate as a solution to the problem of the Armenti Coffee House.

\section{ACKNOWLEDGMENT}

Thank you to the resource person, Armenti Coffee House, and also the Head of the Business Unit at the Armenti Coffee House, Mr. Dwi Anggiadi. Thank you to PPM Telkom University for providing internal funding for this research.

\section{REFERENCES}

Hoolwerff, D. Van. 2014. Does Your Mascot Match Your Brand Personality? University of Twente. Judisseno, R. K. 2019. Aktivitas dan Kompleksitas Kepariwisataan. Jakarta: PT. Gramedia Pustaka Utama. 
Kotler, Philip and Keller, K. L. 2016. Marketing Management. Global. Essex, England: Peason Education. Kusrianto, A. 2009. Desain Komunikasi Visual. Yogyakarta: Andi Offset.

Moriarty, Sandra, Mitchell, Nancy, and Wells, W. 2012. Advertising \& IMC. principles. New Jersey: Peason Education.

Pratiwi, G. and Sumargono, I. 2019. Designing Campaign of Speech Delayed to the Children for Parents in Bandung.

Sugiyama, K. and Andree, T. 2011. The Dentsu Way, Journal of Chemical Information and Modeling. doi: 10.1017/CBO9781107415324.004.

Swasty, W. 2016. Branding. Memahami d. Bandung: PT. Remaja Rodakarya Offset. 